GLOBAL JOURNAL OF SOCIAL SCIENCES VOL 15, 2016: 27-37

COPYRIGHTC BACHUDO SCIENCE CO. LTD PRINTED IN NIGERIA. ISSN 1596-6216 www.globaljournalseries.com; Info@globaljournalseries.com

\title{
STRATEGIC HUMAN RESOURCE MANAGEMENT PRACTICES AND ORGANIZATIONAL GROWTH: A THEORETICAL PERSPECTIVE
}

\section{SUNDAY ISAAC ENEH AND NSOBIARI FESTUS AWARA}

(Received 7 April 2016; Revision Accepted 8 August 2016)

\begin{abstract}
This paper examined the theoretical perspectives of Strategic Human Resource Management Practices (SHRMPs) and organizational growth. The essence was to establish a relationship between SHRMPs and organizational growth. A qualitative research approach was adopted in an attempt to draw a relationship between SHRMPs and organizational growth. Other related works by different authors were reviewed. The findings could be generally stated that SHRMPs have positive and significant influence on organizational growth. The study revealed that it is necessary for organizations to use their human resources effectively in order to minimize wastages. Also SHRMPs, can only be a source of sustained competitive advantage when Human Resource (HR) managers support resources or competencies that provide value to an organization. Given the increased emphasis on HR practices, the study recommended that, it is imperative for Human Resource $(H R)$ to understand the critical nature and utmost importance of effectiveness of all SHRMPs such as training, planning, reward, recruitment, selection and promotion in creating value for the organization.
\end{abstract}

KEYWORDS: Human Resource Management Practices, Organizational Growth,

\section{INTRODUCTION}

Human Resource $(\mathrm{HR})$ is staring at an incredible opportunity to increase organizational performance and become a true strategic partner by contributing to the organization and work design challenges that enables organizational growth. Human resources are the most vital resources for any organization, they are responsible for each and every decision taken, each and every work done and every result. An integral part of human resource management which helps in motivating the employees and improving organizational effectiveness and growth is reward system (Naukrihub, 2009). Strategic human resource management and organizational theories suggest that appropriate use of people enhances organizational effectiveness and growth (Authur 1994, Heskett,
Sasser, and Schlesinger 1997, Tsui, Peacre, and Porter, 1997). Organizations need to exploit all the available resources within its disposal as a means of achieving competitive advantage.

Human beings, more than any other resources, determine the success or failure of their organizations. According to Duke II and Udono (2012), in any private or government, profit or not profit establishment, it is people that set the agenda, objectives and strategies; they create, design, produce and deliver the goods and services and control their quality; they procure, allocate and distribute financial resources, as well as market and sell the end products or services of the organization.

SHRMPs have become major concern for modern managers because organizations achieve their goals and objectives through the efforts of others, and this require the

Sunday Isaac Eneh, Department of Business Management, Faculty of Management Sciences, University of Calabar, Calabar, Cross River State, Nigeria.

Nsobiari Festus Awara, Department of Marketing, Faculty of Management Sciences, University of Calabar, Calabar, Cross River State, Nigeria. 
effectiveness and efficient management of people in them. The persistent change in today's business environment has prompted the adoption of SHRMPs for achieving competitive advantage. Inyang (2010) emphasized that an organization requires the utilization of complex array of resources to grow, survive and achieve the ultimate mission or objectives that informed its existence or creation.

Khan (2010) maintained that human resource has been recognized as a strategic tool, essential to organizational profitability and sustainability. So central is the role of people, that it can be safely argued that they are the most important, influential and responsible resource for efficiency and effectiveness of an organization (Milkovich \& Boudreau, 2004).

\section{CONCEPT OF STRATEGIC HUMAN RESOURCE MANAGEMENT}

Human Resource Management (HRM) is a strategic and coherent approach to the management of an organization's most valued assets-the people working there who individually and collectively contribute to the achievement of its objectives (Armstrong, 2006). Storey (1989) regards HRM as a set of interrelated policies with an ideological and philosophical underpinning. In this age of rapid technological development, the importance of human resources hold the key to the development and growth of an organization. Strategic human resource management is a new approach, that helps in aligning the skills present in the employees with the goals to be achieved by the organization. SHRM is a branch of HRM (Truss \& Gratton, 1994).

Strategic human resource management (SHRM) can be defined as the linking of organizations' strategic human resource management function as a strategic partner to organizational growth in the formulation and implementation of the organization's strategies through human resource activities such as recruiting, selecting, training and rewarding of personnel (Sinha, 2014).

SHRM aligns human resource function to core business objectives. Human resource is at the center of organizational success, people are used in facilitating everything that the organization does. Effective HRM requires that organizations recognize their people as their most important asset. Resources are the inputs or the factors available to a company which help to perform its operations or carry out its activities (Grant, 1991). Managing employees effectively requires a lot of hard work on a continuous basis. Any organization that recognizes the crucial role of its employees and value them for what they are and what they are capable of, will reap the benefit.

SHRM is designed to help organizations best meet the needs of their employees while promoting organizational goals. SHRM requires thinking ahead, and planning ways for an organization to better meet the needs of its employees, and for the employees to better meet the need of the organization.

Organizations that work hard to meet the needs of their employees can cultivate a work atmosphere conducive to productivity and growth, and SHRM is the best way to achieve this. Being able to plan for the heads of employees by thinking ahead can help to improve the rate of skilled employees, who chose to work for the organization. Improving the employees' retention rate can reduce the money organizations needs on finding and training new employees. Understanding the potential of the organization's resources and optimizing the output of such factors, provides an impetus for $\mathrm{HR}$ to become the key ingredient of creating competitive advantage for the organization (Sunil, 2003).

Growth is something for which most large or small organizations, strive to achieve. Small firms wants to get big, big firms want to get bigger. Cosby (1990) observed that if for no other reason that develop over the years, there are many parameters an organization can select to measure its growth. The most meaningful yardstick is the one that shows progress with respect to an organization's stated goals.

The ultimate goal of most organizations is profit, so net profit, relevance, productivity, sales figures, number of employees, physical expansion, and other financial data are often utilized as 'bottom-line' indicators of growth.

\section{STATEMENT OF THE PROBLEM}

The human resource department does much more than just recruiting employees for the organization. Ensuring an effective reward system and using the human resource effectively in order to achieve organizational growth, give the organization a competitive advantage and 
completing the set targets are some of the major concerns and priorities.

Human resources seek to guide their organization through periods of growth. Whether the growth is dramatic or incremental, organizations often encounter difficulties in the process. Organizational growth, however, brings with it an inevitable dilution of that hands-on capability, while the complexity of various organizational tasks simultaneously increases. As the organizations grows and increase in size, control becomes more complex. Growth in organizations makes planning for training, reward, additional recruitment, and even promotion more difficult. Due to difficulties in planning for the implementation of these practices, organizations face down turns in development, profitability, competitive advantage and growth.

Human resource and organizations face a dizzying array of organizational tasks that have to be revised in accordance with changing realities. Maintaining effective methods of communication with and between employees and departments, for example, become ever more difficult but important as the firm grows. Similarly, good human resource management practices, from hiring to training to empowerment, have to be implemented and maintained. Establishing and improving standard practices are often key elements of organizational growth as well. A business that undergoes a significant burst of growth finds its operations transformed in a number of ways. And often, it will be the owner's advance planning and management of the skills that will determine whether that growth is sustained, or internal constraints rein in that growth prematurely. This paper seeks to narrate the implications of training, reward systems, recruitment, and planning as some of the strategic human resource management practices in relation to their degree of impact on organizational productivity, profitability, competitive advantage and development of an organization as measures of organizational growth.

\section{OBJECTIVES OF THE STUDY} include: (i) To determine the degree of relationship between training and productivity in an organization.

(ii) To examine the degree of relationship between reward systems and profitability in an organization.

(iii) To ascertain the extent to which recruitment relate to competitive advantage in an organization.

(iv) To assess the usefulness of planning with respect to development of an organization.

\section{SIGNIFICANCE OF THE STUDY}

The importance of this study will include the following:

- The study will add to the existing literature on HRM practices and organizational growth.

- The study will spur on additional research in the studied area.

- The study will provide organizations a holistic view on the extent to which training, reward systems, recruitment and planning could aid organizational productivity, profitability, competitive advantage and development.

\section{RELATED WORKS}

Mohrmans (2007) studied design of organizations for growth: The human resource contribution, explores the key issues raised in designing an organization for rapid growth and how HR should contribute to this. Understanding organization design approaches for growth, leading design processes, and building the capabilities for growth into the organization are critical strategic contributions for HR professionals. To play this role, HR need to develop new skills in organization design, be involved in helping the business think through how it should be structured, and build growth routines into the organization (Mohrman, 2007). Questionnaires were developed to ascertain the extent of the human resource contribution on organizational design for growth. Data from the study were analyzed using Pearson product moment correlation coefficient. The study revealed that talent management (maximizing human resource potentials) is inextricably linked to organization and work systems design, in a way that each compliment the other. Whether seeking organic growth in new markets, 
expanding through developing innovative products, services, and business models, or growing through acquisitions and partnerships, organizations face the need to find and integrate new resources, realign existing ones, and reconfigure core design features to handle the increased size and complexity that accompany growth.

The study therefore concluded that to support growth strategies, HR's definition of talent management has to be expanded to include designing the context in which talent operates. The ability to optimize talent strategy is in profound interdependence with how the organization is designed to function. Must expand its domain of influence by becoming proficient at shaping the design of the organization for growth.

Mohrman (2007) describes the domain of organization and work design expertise, design challenges that HR must address to support different kinds of growth strategies, the competencies that HR needs to learn to be major players in this domain, as well as some of the approaches that can be used to build the foundation for this capability. A well designed organization uses its talent effectively, which limits the waste that occurs when valuable talent hours are used poorly, avoiding the frustration, cynicism, and unnecessary withdrawal of the talent that HR works so hard to build.

Schuler and Macmillan (1984), in agreement with Mohrman (2007), pointed out that the basic functions of SHRM involve designing and implementing a set of internally consistent policies and practices that ensure the human capital of a firm contributes to the achievement of its business objectives. SHRM reflects a more flexible arrangement and utilization of HR to achieve the organizational goals and accordingly helps organizations gain a competitive advantage (Jackson and Schuler, 1995). Importantly, SHRM emphasizes developing the firm's capacity to respond to the external environment through a better deployment of human resources.

Conner and Ulrich (1996) stated in their study on "human resource roles: Creating value, not rhetoric" that what is needed is HR function that expands its focus beyond its traditional operational and transactional role. To improve its effectiveness and have greater impact, the HR function must understand how to add value in the organization by helping line managers align HR strategies, processes, and practices with business needs. Questionnaire was constructed to test the extend to which HR roles could be defined and measured. Items were developed around the four key roles, outlined by Ulrich (1993) - that is, strategic partner, change agent, employee champion, and administrative expert.

Data from the study were subjected to factor analysis in order to investigate the number and kinds of factors that could be determined from the data. Simple statistics and Pearson product moment correlation coefficients were also calculated with respect to each of the four roles. Findings revealed that scores were higher for the employee champion and administrative expert roles and lower for the strategic partner and change agent roles. This is consistent with the traditional human resource roles. The lowest score is the strategic partner role. The study confirms the existence of discrete multiple roles that human resource people play and suggests that, it is important that these roles are communicated clearly to human resource people so that they can continue to build their skills, knowledge, and abilities.

Conner and Ulrich (1996) observed that business executives worldwide are concerned with the effectiveness and value of the human resource function. Organizations are discovering the need to reinvent the human resource function. To improve its effectiveness and have greater impact, the human resource function must understand how to add value in the organization by helping line managers align HR strategies, processes, and practices with business needs. HR's roles in creating value and building a competitive organization according to Ulrich (1997), include: management of strategic human resources, transformation and changes, firm infrastructure and employees contributions.

Collins (1987) observed in this study on the strategic contributions of the human resource function that, consideration of the strategic contributions of human resource management to organizational functioning and performance require a qualitatively different approach from that accorded traditional perspectives of personnel management. The strategic contributions of the human resource function to organizations are examined at both the corporate and business levels. It is argued that at both levels issues arising from the 
management of people are central to the formulation and implementation of strategies.

Collins emphasized the need to establish alignment between organization's mission, strategy, structure, culture, workforce characteristics and personnel policies and practices. The study was concerned primarily with the choice of a strategy that aligns the organization's resources and competencies with the opportunities and constraints that characterized chosen environment. However, many organizations are underperforming because of incongruencies between their strategies and structure, and particularly their culture and workforce competences and attitudes. He suggested that senior managers and personnel specialists need to adopt a strategic mindset in order to conceptualize the issues and identify appropriate actions. Improvement in the strategic management of people in organization requires a commitment to sustained long term action. Therefore, skills, patience, and courage will be required to hold in place the necessary initiatives which will improve the contribution of the personnel function to organizational success and growth.

Collins (1987) understanding the potential of an organization's resources, optimizing the output of such resources and given the changes, provide an impetus for HR to become the key source of creating the competitive advantage for the organization. In today's business environment, organizations constantly need to evaluate their environments, their internal and external environment for challenges and opportunities to remain competitive and to sustain growth. Political, economic, social, and even psychological changes within our societies have a significant impact on business organizations.

$$
\text { Many factors drive changes in }
$$
organizations today, including the use of technology, globalization, changes in workforce demographics, the elimination of bureaucracies in organizational structures, and the need to find a balance between work and family issues. To create value and deliver results, HR professionals must begin not by focusing on the work activities or work of HR but by defining the deliverables of that work. According to Sorensen (1995), the best way for HRM to gain credibility in order to make meaningful changes is for practitioners to measure the cost and effectiveness of what they do. So, given the increased emphasis on HR practices, it is imperative for $\mathrm{HR}$ to be able to show its effectiveness in creating value for the organization.

\section{CONCEPTUAL REVIEW OF SHRMPS}

Strategic human resource management (SHRM) will continue to grow in importance in the success story of organizations, as the world of business becomes more complex and challenging. It is very certain that employees (human resources) continue to play pivotal roles as the creativity and innovative ideas reside in this vital resource management.

$\mathrm{HR}$ an organization's workforce, and its management is essential for the overall growth and development of the firm. Human resource management is responsible for the attraction, selection, training, assessment and rewarding employees in an organization. Thus, strategic human resource management practices (SHRMPs) are obviously directed at achieving organizational objectives.

Daughtry and Ricks (1989) noted that employees for a variety of reasons often need training to increase their productivity. The essence of employee training is that, in organization where opportunity to grow and advance exist, it does not only improve the morale of employees but also offers inducement for outsiders to accept employment in the organization. Hussay (1998) recommends training as an important implementation tool for achieving organization success, not only because it motivates people but it also provides employees the skill required for strategy implementation.

Maintaining a high productivity is the life of any successful business all around the world. No matter how much money an organization invests in business, without productivity and implementation of strategies, the business would not progress and would eventually collapse. Inyang (2004) defines productivity as the ratio of total output to total inputs. Ensuring an effective rewards system would help an organization achieve high productivity and profitability.

Kreitner (1995) emphasizes that organizational rewards are the materials and psychological pay-offs for doing something. Therefore, when employees are not adequately rewarded or compensated, productivity suffers 
and profit dwindles. Compensation management is one of the important responsibilities of HR. Organizations need to implement an effective salary and benefits package to attract good talents (recruits) and motivate employees to perform to the best of their ability.

Fitz-enz (2002) describes the need to ensure that the recruitment function is efficient. He further stated that it is better to measure recruiters as a team than as individual whenever applicable. In determining recruiter team efficiency. Fitz-enz stated that HR measurements attempts (strategies) should focus on the productivity of their interviewing techniques, the average length of interviews for the respective job groups, and the number of interviews needed to make a quality hire.

$\mathrm{HR}$ planning involves the process that specifies the activities a firm must use in order to develop its human resources to improve its overall practices (Gatewood \& Field, 2001). According to Wofford (2002), strategic planning and formulation of $\mathrm{HR}$ framework to align employees to corporate organizational plans and objectives are necessary. Strategic planning seeks to identify the organizational decisions and actions that yield the greatest advantage under various assumptions about the organization and its environment. Wofford emphasized the integration of $\mathrm{HR}$ in the organizational strategy as the basis for enabling the HR function to support and implement the strategic plan to achieve competitive advantages.

Strategic human resource development increases the competence of employees in an organization. Developing employees is a HR practice used in increasing productivity and thus helping people and organization become more successful for years to come.

\section{THEORETICAL REVIEW AND FRAMEWORK}

Human resource $(\mathrm{HR})$ practice is the management process of an organization's workforce, assessment, and rewarding of employees, while also overseeing organizational leadership and culture as well as ensuring compliance with employment and labour laws.

$\mathrm{HR}$ is a product of the human relations movement of the early $20^{\text {th }}$ century when researchers began documenting ways of creating business value through the strategic management of the workforce. The function was initially dominated by transactional work, such as payroll and benefits administration, but due to globalization, company consolidation, technological advancement, and further research, $\mathrm{HR}$ now focuses on strategic initiatives like mergers and acquisitions, talent management, succession planning, industrial and labour relations, and diversity, (Ulrich, 1996).

Many organizations, practitioners, academics, etc, all seek to engage and further the field of $\mathrm{HR}$, as evidenced by several fieldspecific publications. Organizations are focused on retaining the talent and knowledge held by the workforce, lowering the employee turnover and preserving knowledge. HR department also strives to offer benefits that will appeal to workers, thus reducing the risk of losing knowledge.

Collins (1986) stresses the need for managers to enhance their capacity to manage strategically rather than operationally. This shift necessitates that managers develop new competences and adopt different ways of looking at and thinking about their organizations and environments.

Today, organizations find that competitive conditions, technological capabilities, fashion and customer preferences change so dramatically and quickly that growth strategies involve combination of organic and externally fueled growth (Lawler \& Worley, 2006). For growth to occur, the organization has to organize its talent differently to carry out new work and secure new talent. Lawler and Worley (2006) emphasize that growth strategies often are conceived in uncertain environments that require organizational flexibility and that organizations must be built to change or adaptable to changes.

Resource-based view theory is the theoretical underpinning of this study. Resourcebased view (RBV) as influential body of research within the field of strategic management was named by Birger Wernerfelt in his article. A Resource-Based view of the firm (1984). Two publications closely following Wernerfelt's initial article came from Barney (1986a, 1986b). Even though Wernefelt was not referenced directly, the statements made by Barney about strategic factor markets and the role of expectations can clearly be seen with the resource- based framework as later developed by Barney in 1991. Other concepts that were later integrated into the resource-based framework are uncertain 
inimitability (Lippman \& Rumelt, 1982), isolating mechanisms (Rumelt, 1984), inimitability (Dietickx and Cool: 1989).

A resource-based view (RBV) of a firm explains its ability to deliver sustainable competitive advantage when resources are managed such that their outcomes cannot be imitated by competitors, which ultimately creates a competitive barrier (Mahoney \& Pandian, 1992). RBV explains that a firm's sustainable competitive advantage is reached by virtue of unique resources being rare, valuable, inimitable, non- tradable, and non-advantage through unique resources which it holds, and these resources cannot be easily bought, transferred, or copied, and simultaneously, they add value to a firm while being rare (Barney, 2001). Major concern in RBV is focused on the ability of the firm to maintain a combination of resources that cannot be possessed or built up in a similar manner by competitors. In other words, if the resources a firm employs cannot be easily imitated by another firm or substituted by similar resources another firm employs, the firm can take advantage of this to gain competitiveness not simultaneously pursued by other firm. This translate into valuable resources that are neither perfectly imitable nor substitutable without great effort (Barney, 1991).

These resources fulfill the following criteria referred to as VRIN (valuable, rare, inimitable, and non- substitutable).

- Value-A resource must enable a firm to employ a value-creating strategy, by either outperforming its competitors or reduce its own weaknesses. According to Mahoney and Pandian (1992), the relevant perspective in this is that, the transaction costs associated with the investment in the resource cannot be higher than the discounted future rents that flow out of the value-creating strategy.

- Rare-To be of value, a resource must be rare by definition. In a perfectly competitive strategic factor market for a resource, the price of the resource will be a reflection of the expected discounted future above-average returns (Dierickx \& Cool, 1989).

- In-imitable-If a valuable resource is controlled by only one firm, it could be a source of a competitive advantage. This advantage could be sustainable if competitors are not able to duplicate this strategic asset perfectly (Peteraf, 1993). The term isolating mechanism was introduced by Rumelt (1984) to explain why firms might not be able to imitate a resource to the degree that they are able to compete with the firm having the valuable resource (Mahoney \& Pandian, 1992). An important underlying factor of inimitability is causal ambiguity, which occurs if the source from which a firm's competitive advantage stems is unknown (Lipmann \& Rumelt, 1982). If the resource in question is knowledgebased or social complex, causal ambiguity is more likely to occur as these types of resources are more likely to be idiosyncratic to the firm in which it resides (Peteraf, 1993).

- Non-substitutable - Even if a resource is rare, potentially value-creating and imperfectly imitable, an equally important aspect is lack of substitutability (Dierickx \& Cool, 1989). If competitors are able to counts the firm's value-creating strategy with a substitute, prices are driven down to the point that the price equals the discounted future rents, resulting in zero economic profits (Barney, 1986a). Organizations should therefore, care for and protect resources that possess these evaluations, because doing so can improve and sustain organizational performance and growth (Crook, Ketchen, Combs \& Todd, 2008).

The Resource-Based View (RBV) as a basis for the competitive advantage of a firm lies primarily in the application of a bundle of valuable tangible or intangible resources at the firm's disposal (Penrose, 1959). It is perhaps difficult (if not impossible) to find a resource which satisfies all of the Barney's 1991 VRIN criteria, the theory has limited prescriptive implications.

Barney (2001) stated that, his theory applies to static environments, but not to dynamic environments, as today's business realities are clearly not static but dynamic and characterized by high velocity and rapid change. He thus admitted that his 1991 VRIN criteria have little potential for applicability to the real world. It does, however, provide a good way for 
senior managers to better understand their resource base. In business reality, senior managers are often not interested whether or not the RBV constitutes a real theory or not. Instead, they require guidance for achieving competitive survival which believes is more important.

The RBV provides the understanding that certain unique existing resources will result in superior performance and ultimately build a competitive advantage. Sustainability of such an advantage will be determined by the ability of competitor to imitate such resources. However, the existing resources of a firm may not be adequate to facilitate the future market requirement, due to volatility of the contemporary markets. There is a vital need to modify and develop resources in order to encounter the future market competitions. An organization should exploit existing business opportunities using the present resources while generating and developing a new set of resources to sustain its competitiveness in the future market environment. Hence, an organization should be engaged in resource management and development in order to sustain competitive advantage and strengthen the firm's ability to continue the superior performance (Peteraf, 1993).

\section{RECOMMENDATIONS} made:

The following recommendations were

- HR should be seen and valued as asset, that contribute significantly to the growth of the organization.

- Organizational growth depends strongly on SHRMPs such as training, planning, reward, recruitment, selection and promotion. Thus, organizations should emphasize more on implementation of such SHRMPs, to foster organizational growth.

- HR managers and practitioners should understand the critical nature and utmost importance of understanding the effectiveness of all SHRMPs in creating value for the organization.

- HR managers should be encourage to implement these SHRMPs so as to enhance organizational productivity and growth.

\section{CONCLUSION}

SHRMPs enable organization to achieve optimization of resources, efficiency and effectiveness, and continuous improvement in realizing its set goals. SHRMPs are characterized by valuing employees as essential assets and core partners in creating competitive advantage in the organization.

Strategic planning seeks to identify the organizational decisions and actions that yield the greater advantage under various assumptions about the organization and its environment. According to Wofford (2002), the integration of human resources into the organizational strategy provides the basis for enabling the HR function to support and implement the strategic plan to achieve a competitive advantage.

It is also necessary to develop and update human resources as a major management responsibility since all business environments reflect highly unpredictable market and environmental conditions. The existing winning edge needed to be developed since various market and environmental changes may make existing value- creating resources obsolete.

SHRM covers a wide range of activities from organizational positioning (reputation), as an organization of choice for prospective employee, in its reward systems, recruitment, training and development of employees, and objective not only targeted toward better customer service delivery, but also for the retention of the firm's best performers and organizational growth.

Training is an important aspect of SHRM practice. Training impacts basic skills to new recruits, create positive changes in employees' behaviour and attitude to work. Knowledgeable and highly skilled employees improve organizational productivity and profitability, create competitive advantage, and facilitate growth of an organization.

Business organizations constantly need to evaluate their internal and external environments for challenges and opportunities to remain competitive and to sustain growth. Political, economic, social, and even psychological changes within our societies have significant impacts on organizations. 
Therefore, it is necessary to develop and update resources as a major management responsibility since all business environments reflect highly unpredictable market and environmental conditions. Organizations need to develop winning edge strategies and practices since various market changes may make existing value-creating resources obsolete.

\section{REFERENCES}

Armstrong, M., 2006. A handbook of human resource management practice. $10^{\text {th }}$ Edition. New Delhi: Kogan Press.

Arthur, J., 1994. Effects of human resources systems on manufacturing performance and turnover. Academy of Management Journal, 37,670-687.

Barney, J. B., 1980b. Organizational culture: Can it be a source of sustained competitive advantage? Academy of Management Review: 11, (3): 656-665.

Barney, J. B., 1986a. Strategic factor markets: Expectations, luck and business strategy. Management Science; 32, (10): 1231-1241.

Barney, J. B., 1991. Firm resources and sustained competitive for strategic management research? Yes. Academy of Management Review; 26, (1): 41-56.

Boxall, P., 1992. Strategic human resource management: Beginnings of a new theoretical sophistication. Human Resource Management Journal, 2, (3):

Collins, R. R., 1986. The strategic contributions of human resources development. Unpublished paper delivered to the AITD National Conference. Hobart (1987) April.

Collins, R. R., 1987. The strategic contributions of the human resource function. Asia Pacific Journal of Human Resources; 25, (5): 5-20.
Conner, J and Ulrich, D., 1996. Human resource roles: Creating value, not rhetoric. Human Resource Planning; 19, (3):1-10.

Cosby, P. B., 1990. The eternally successful organization: The art of corporate wellness. New York: New American Library.

Crook, T. R., Ketchen, Jr., D. J., Combs, J. G and Todds, S. Y., 2008. Strategic resources and performance: A meta-analysis. Strategic Management Journal; 29,1141-1154.

Daughtry, A. H and Ricks, B. R., 1989. Contemporary supervision: Managing people and technology. New York: McGraw-Hill.

Dierickx, I and Cool, K., 1989. Asset stock accumulation and sustainability of competitive advantage. Management Science; 35, (12): 1504-1511.

Duke II, J and Udono, E. N., 2012. A new paradigm in traditional human resource management practices. Journal of Management and Sustainability; 2, (2): 146-159.

Fitz-enz, J., 2002. How to measure human resource selection ( $3^{\text {rd }} E d$.). City: McGraw Hill.

Gatewood, R and Field, H., 2001. Human resource selection ( $5^{\text {th }}$ Ed.). Mason, Ohio: South Western.

Grant, R. M., 1991. The resource-based theory of competitive advantage: Implications for energy formulation. California Management Review; 33(3):114-135.

Haskett, J., Sasser, W and Schlesinger, L., 1997. The service profit chain: How leading companies link profit and growth to loyalty, satisfaction, and value. New York, Free Press.

Hussay, D. E., 1998. Managing training and corporate strategy: How to improve competitive performance. Oxford: Pergamon Press. 
Inyang, B. J., 2004. Management theory: Principles and practice. ( $2^{\text {nd }}$ Ed.) Calabar: Merb Publishers.

Inyang, B. J., 2010. Strategic human resource management (SHRM): A paradigm shift for achieving sustained competitive advantage in organization. International Bulletin of Business Administration, 7, (23):215-243.

Iwaugwu, C. E., 2004. Statistics for practical applications: Design making. Owerri: Nation-Wide Publishers.

Jackson, S. F and Schuler, R. S., 1995. Understanding human resource management in the context of organizations and their environment. Annual Review of Psychology, 46, 237264.

Khan, M. A., 2010. Effects of human resource management practices on organizational performance. An empirical study of oil and gas industry in Pakistan. European Journal of Economics, Financial and Administrative Sciences, 24, (158): 1450-2275.

Kreitner, R., 1995. Management. (6 $6^{\text {th }}$ Ed.). Boston: Houghton Mifflin Company.

Lawler, E. E and Worley, C., 2006. Built to change: How to achieve sustained organizational effectiveness. San Francisco: Jossey-Bass.

Lippman, S. A and Rulmelt, D. P., 1982. Uncertain inimitability: An analysis of interim differences in efficiency under competition. The Bell Journal of Economics; 13, (2): 418-438.

Mahoney, J. T and Pandian, J. R., 1992. The resource-based view within the conversation of strategic management. Strategic Management Journal: 15, (5): 363-380.

Milkovich, G. T and Boudreau, J. W., 2004. Personnel human resource management: A diagnostic approach. $\left(5^{\text {th }}\right.$ Ed.) Illinois: Richard D. Irwin.

Mohrman, S. A., 2007. Designing organizations for growth: The human resource contribution. Human Resource Planning; 30, (4): 1-11.

Naukrihub, 2009. Payroll system and compensation management. www.payroll.naukrihub.com/compensatio n.jtml.

Penrose, E. T., 1959. The theory of the growth of the firm. New York: John Wiley.

Peteraf, M. A., 1993. The cornerstones of competitive advantage: A resourcebased view. Strategic Management Journal; 14, (3): 179-191.

Rumelt, D. P., 1984. Towards a strategic theory of the firm. Alternative theories of the firm. International Library of Critical Writings in Economics; 154, (2): 268300.

Schuler, R. S and Macmillan, I. C., 1984. Gaining competitive advantage through human resource management practices. Human Resource Management: 23, (3): 241-256.

Sinha, R., 2014. What is strategic human resource management. (http://Ezine Artic les.com/expert).

Sorensen, N. M., 1985. Measuring human resource management's effectiveness in improving performance. Human Resource Planning; 26, (1): 51-66.

Sunil, J. R., 2003. Measuring human resource management's effectiveness in improving performance. Human Resource Planning; 26, (1): 51-66.

Truss, C and Gratton, L., 1994. Strategic human resource management: A conceptual approach: International Journal of Human Resource Management, 5, (3): 
Tsui, A., Peacre, J., Porter, L and Tripoli, A., 1997. Alternative approaches to the employeeorganization relationship: Does investment in the employees pay off? Academy of Management Journal, 40,1089-1121.

Ulrich, D., 1993. The resource partnerships: From Rhetoric to Results. Unpublished manuscript.

Ulrich, D., 1996. Human resource champions: The next agenda for adding value and delivering results. Cambridge, Mass: Harvard Business School Press.

Ulrich, D., 1997a. Human resource champions: The next agenda for adding value and delivering results. Boston: Harvard Business School Press.

Wernerfelt, B., 1984. A resource-based view of the firm. Strategic Management Journal; 5, 171-180.

Wofford, T., 2002. Competitive advantage: Strategy and human resources. Applied Management and Entrepreneurship; 7, (1): 135-147. 